\title{
İnfaz Koruma Memurlarının İş Doyumu ve Örgütsel Bağlılıkları: Batı Karadeniz Bölümü Örneği ${ }^{1}$
}

\author{
Nuray Türkera* ${ }^{a}$ İsmail Öztürk ${ }^{b}$ \\ ${ }^{a}$ Karabük Üniversitesi, Safranbolu Turizm Fakültesi, Karabük. \\ ${ }^{b}$ Karabük Üniversitesi, Sosyal Bilimler Enstitüsü, Karabük.
}

\section{$\ddot{O} z$}

$\mathrm{Bu}$ çalışmanin temel amacl, Ceza İnfaz Kurumlarında çalışan infaz koruma memurlarının iş doyumlarının, örgütsel bağhlliklarının ve iş doyumunun kurumlarına olan bağlilığg arttırıp artırmadığının belirlenmesidir. Çalışmada Batı Karadeniz Bölümü'nde [Karabük (Merkez ve Eskipazar ilçesi), Bartın, Kastamonu, Bolu, Zonguldak illerinde] hizmet veren ceza infaz kurumlarında yapılan ampirik bir çalışmadan elde edilen bulgu ve sonuçlar sunulmaktadır. Ana kütleyi temsil eden 524 infaz koruma memuru üzerinde yapılan çalışmanın sonuçları incelendiğinde; ceza infaz koruma memurların genel olarak çalıştıkları işten elde ettikleri doyumun düşük olduğu, iş doyumundaki artışın örgütsel bağhllı̆g pozitif yönde etkilediği görülmektedir. Ayrıca çalışmada memurların örgütsel bağhllıklarm kurumun bulunduğu yere göre farklılık gösterdiği tespit edilmiştir.

Anahtar Sözcükler: İş doyumu, örgütsel bağlllık, infaz koruma memurları, Batı Karadeniz Bölümü.

\section{Job Satisfaction and Organizational Commitment of Correctional Officers: A Survey in Western Black Sea Region}

\begin{abstract}
The main aim of this study is to determine the job satisfaction and organizational commitment of correctional officers and also to identify whether job satisfaction increases the commitment of officers or not. In this paper, findings of an empirical study that is conducted in the Correctional Institutions in Western Black Sea Region [in the provinces of Karabük (Centre ve Eskipazar district), Bartın, Kastamonu, Bolu, and Zonguldak] are presented. The findings of the survey which is conducted with 524 correctional officers show that job satisfaction of correctional officers is low and the increase in job satisfaction affects the organizational commitment positively. It is also find out that the organizational commitment of the officers varies according to the location of the correctional institution.
\end{abstract}

Keywords: Job Satisfaction, Organizational Commitment, Correctional Officers, Western Black Sea Region.

\footnotetext{
${ }^{1}$ Bu çalışma Karabük Üniversitesi Sosyal Bilimler Enstitüsü'ne sunulan İnfaz Koruma Memurlarının İş Doyumu ve Örgütsel Bağllıklarını Belirlemeye Yönelik bir Araştırma adlı yüksek lisans tezinden üretilmiştir.

*Yazışma adresi. Email: nturker@karabuk.edu.tr
} 


\section{GíRiş}

Modern anlayışa göre örgütler, belli amaçları gerçekleştirmek üzere bir araya gelen insanlardan oluşan dinamik yapılardır. Dolayısıyla örgütlerin, dünyada yaşanan insan hakları, eşitlik ve demokrasinin yaratmış oldukları değişime ayak uydurmaları ve varlıklarını sürdürebilmeleri için en önemli faktörlerden biri olan insan faktörünü etkili kullanmaları zorunluluk haline gelmiştir. Örgütlerin başarılı olabilmesi ve müşteri memnuniyeti yaratacak nitelikli hizmetler üretebilmeleri çalışanların işten duydukları tatmin ve memnuniyet düzeyine bağlıdır. 21. yüzyıl yönetim anlayışı işgörenlerin iş doyumunu sağlamak üzerine kurulmuş misyonların ve iş doyumunu arttırmak amacıyla geliştirilmiş stratejilerin kurumların yaşamını sürdürmesinde zorunlu olduğunu ortaya koymuştur. Her örgütte iş doyumu oldukça önemli bir konu olmakla birlikte, çalışma koşulları bakımından zor koşullarda çalışan infaz koruma memurlarının örgütsel bağlılığı açısından iş doyumu daha da büyük önem taşımaktadır.

Örgüt ve işgören ilişkisi sonucunda oluşan ve işgörenin örgüte karşı hissettiği bağın gücünü ifade eden örgütsel bağlılık örgütün performansını etkilemektedir. Bu nedenle örgütlerin, işgörenlerin yaptıkları işten ve çalıştıkları örgütten memnun olmalarını sağlamak ve işgörenlerin örgüte bağlllıklarını arttırmak için etkin çaba harcamaları gerekir. İnfaz koruma memurlarının örgütsel bağlılıkları, onların örgütlerine ve işlerine karşı olan tutumlarını olumlu yönde etkileyecektir. İnfaz koruma memurları, ceza infaz kurumlarının fiziki yapıları ve işin çalışanlar üzerinde yarattığı psikolojik baskı nedeniyle aşırı derecede yıpranmaktadır. Bu nedenle infaz koruma memurlarının, olumlu koşullarda çalışmasını sağlamak, işleri ile ilgili olumlu tutum ve davranışlarını artırmak yoluyla ceza infaz kurumlarında gerçekleştirilen ıslah çalışmalarını daha etkin kılmak ve yine bu yolla ceza infaz kurumlarının güvenliğini artırmak amaciyla infaz koruma memurlarının iş doyumu ve örgütsel bağlılık düzeylerinin belirlenmesi önem taşımaktadır.

Bu çalışmada Batı Karadeniz Bölümünde [Karabük (Merkez ve Eskipazar ilçeleri), Bartın, Kastamonu, Bolu, Zonguldak illeri] faaliyet gösteren ceza infaz kurumları memurlarının iş doyumlarının ve örgütsel bağlılık düzeylerinin belirlenmesi amaçlanmaktadır. Bu amaçla çalışmanın ilk bölümünde literatür bilgilerine yer verilmiş, ikinci kısmında ise Batı Karadeniz Bölümünde faaliyet gösteren ceza infaz kurumlarında çalışan infaz koruma memurları üzerinde uygulanan ampirik çalışmanın bulgularına yer verilmiştir.

\section{LITERATÜR}

İş doyumu, genel olarak işin özellikleriyle mutlu olmayı veya işgörenin işinden memnuniyet duymasını ifade etmektedir (Mohamed vd., 2012: 1). İş doyumu, bir bireyin işinin özelliklerinin, kendisi için önemli olan nitelikleri taşıması ve doldurması halinde ortaya çıkan doyum durumudur (Ceylan ve Ulutürk, 2006: 50). İşinden doyum sağlayan işgören bu doyumu işine de yansıtır ve işine karşı olumlu tutum geliştirir. İş doyumu, işgörenin mutluluğunu artırmakla beraber, işgörenin işine bağlanmasına, verimli çalışmasına, işgücü devir oranının düşmesine neden olmaktadır. Aksi 
durumda yani iş tatmininin olmadığı durumlarda yüksek iş gören devir hızı, devamsızlık ve işten ayrılma niyeti artmakta, örgütsel bağlılık zayıflamakta, yabancılaşma, stres, zihinsel ve bedensel rahatsızlıklar ile verimsizlik artmaktadır (Gül vd., 2008: 2).

Günümüz işletmelerin başarısı, insan kaynaklarını organize edebilme ve faaliyetlerini iş doyumu yüksek personelle yürütebilmeleri ile mümkündür (Öztürk ve Güzelsoydan, 2001: 333). Bu nedenle çağdaş yöneticilerden, işgörenlerin iş doyumlarının sağlanması ve artırılması için gereken çabayı göstermeleri beklenmektedir. Her şeyden önce, işgören doyumunu sağlamak için yöneticilerin, işgörenlerin salt bir üretim faktörü olduğu yönündeki önyargılarından kurtulmaları, aynı zamanda sosyal yönlerinin de bulunduğunu, ekonomik beklentilerinin dışında farklı sosyal ve psikolojik beklentilerini ve ihtiyaçlarını karşılamak için çalıştıklarını göz önünde bulundurmaları gerekmektedir (Toker, 2007: 93).

Çalışma ortamında iş doyumunu belirleyen unsurlar arasında; iş çevresi, ücretler, yöneticiler, yükselme olanakları, çalışan ve yöneticilerle ilişkiler gibi pek çok faktör sayılabilir (Demirel ve Özçınar, 2009: 133). Her bireyin bu faktörlere vereceği değer değişebilir. Örneğin; bir işgören için en önemli etken ücret iken, bir diğeri için terfi imkânları olabilir. Herhangi bir bireyin tatmin olduğu koşullardan bir diğer işgören tatmin olmayabilir. Bunun nedeni bireylerin algılarındaki farklılıktır (Yiğit vd., 2011: 6).

İş doyumu ile güçlü ilişkisi olan örgütsel faktörlerden ilki ücrettir. Sönmezer ve Eryaman (2008: 189-209), kamu ve özel eğitim kurumlarında çalışan işgörenlerin iş tatmin düzeylerinin karşılaştırmasına yönelik olarak yaptıkları araştırmada; kamu okullarında görev yapan öğretmenlerle özel öğretim kurumlarına geçiş yapmış olan öğretmenlerin iş doyum düzeyleri arasında istatistiksel olarak anlamlı bir fark olduğunu saptamışlardır. Bu farklılığa neden olan faktörlerden birinin de ücret olduğu tespit edilmiş ve özel kurumlarda çalışan öğretmenlerin ücret konusundaki doyum düzeyleri daha yüksek bulunmuştur.

Kariyer geliştirme, bir işgören için gelişme anlamına gelirken, diğeri için daha çok kazanma, daha yüksek mevki elde etme anlamına gelebilir. Bozkurt ve Bozkurt (2008: 1), iş doyumunu etkileyen işletme içi faktörlerle ilgili olarak yaptıkları araştırmada, iş doyumu ile kariyer arasında olumlu bir ilişkinin olduğu tespit edilmiştir.

İşgörenlerin birlikte çalıştığı iş arkadaşları iş doyumunu etkilemektedir. Kitapçı ve Sezen (2002: 227), çalışanların tatminini belirleyen unsurlar üzerine yaptıkları araştırmada, iş doyumu ve iş arkadaşları ile ilişkiler arasında pozitif yönlü bir ilişki olduğunu saptamışlardır.

İş doyumu ile güçlü ilişkisi olan bir diğer örgütsel faktör yönetim biçimidir. Yapılan araştırmalar, yöneticilerin davranışının iş doyumunu önemli derecede etkilediğini ortaya koymaktadır. Omidifar (2013: 263), yönetici davranışının örgütsel bağlılık ve iş doyumu üzerine etkisini belirlemeye yönelik olarak yaptığ çalışmada, 
yöneticinin davranışı ile iş doyumu arasında pozitif yönlü bir ilişkinin olduğunu tespit etmiştir.

Örgütsel iletişim, bireyin iş doyum düzeyini etkileyebilmektedir (Aşan ve Erenler, 2008: 6). Yüksel (2005: 291) iletişimin iş doyumu üzerindeki etkisini belirlemek amacıyla yaptığı çalışmada iş doyumu ve iletişim arasında anlamlı ve güçlü bir ilişkinin olduğunu tespit etmiştir.

İş doyumu ile yakın ilişkisi olan örgütsel bağlılık; bireyin örgüt içinde kalma isteği, örgütün amaç ve değerlerine olan bağlllı̆̆1 şeklinde tanımlanmaktadır (Çekmecelioğlu, 2006: 155). Chan (2006: 252)'a göre örgütsel bağlılık; örgüt adına gönüllü olarak çaba göstermek, örgüt tarafından tanımlanmış olan amaç ve değerleri kabul etmek ve bu amaçlar doğrultusunda faaliyette bulunmaktır.

Örgütsel bağlılık, bir işgörenin örgüte girmesi ve psikolojik olarak kendisini örgütün bir üyesi olarak hissetmesi ile başlar (Izgar, 2008: 319). Böylece işgören işyerine psikolojik olarak bağlanır, örgütte kalma isteği duyarak örgütün amaç ve değerleriyle özdeşleşir (Balay, 2000: 16). Örgütün değerlerini benimseyen ve örgütsel amaçlara ulaşmak için çaba sarf eden işgörenler örgütsel etkililiğe ve verimliliğe katkıda bulunurlar (Tolay, 2003: 2).

Örgütsel bağllı̆̆ın "duygusal bağlılık", "devam bağlılığı" ve "tutumsal bağlılık" olmak üzere üç boyutu bulunmaktadır. Duygusal bağlılık, bireyin kendisini örgütle özdeşleştirmesini, bütünleştirmesini ifade etmektedir (Tekingündüz, 2012: 2021). Tutumsal bağl1lık, bireyin kimliğinin örgütle özdeşleşmesi ya da örgütün amaçları ile kişisel amaçlarının bütünleşmesi ve amaçların özdeşleştirilip, bu amaçları gerçekleştirmek için örgüt üyeliğini sürdürmeyi istemesidir (Günlük, 2010: 14-15). Devam bağlılığı ise, örgütten ayrılmanın maliyetinin yüksek olduğu veya başka bir alternatifin olmadığı örgütsel bağlılık boyutudur. Örgüte devamlılık bağlılığı ile bağlı olan işgören işine ve örgüte ihtiyacı olduğu için bir bağlılık duyar. Böyle durumlarda işgören örgüte fazlasıyla zaman ve çaba harcadığını düşünmekte ve bunların boşa gitmemesi için örgütte devam etmesinin zorunlu olduğuna inanmaktadır (Altınbaş, 2008: 7).

İşgörenlerin örgüte bağlılık hissetmesi, iş verimlerini arttırarak örgüt için olumlu sonuçlar doğurmaktadır. İşgörenin örgütsel bağlılığının zayıf olması ise işten ayrılma, devamsızlık, işe geç kalma, stres, performans düşüklüğü gibi olumsuzluklar ile sonuçlanabilmektedir. Günümüzde örgüte bağlılığı olan bireyler daha uyumlu, daha doyumlu, daha üretken olmakta, daha yüksek derecede sadakat ve sorumluluk duygusu içinde çalışmakta, örgüte daha az maliyete neden olmaktadır (Albayrak, 2007: 45). Bu nedenle yönetimin, işgörenlerin örgüte bağlılığını arttırabilecek ya da azaltabilecek faktörlerin farkında olması iş başarımı açısından büyük önem taşımaktadir.

Örgütsel bağl1lı̆̆1 etkileyen faktörleri kişisel ve örgütsel faktörler olmak üzere iki başlıkta incelemek mümkündür (Bkz. Şekil 1). Örgütsel bağl1lı̆̆1 sağlayan kişisel faktörlerden ilki psikolojik sözleşmedir. Karcıoğlu ve Türker (2010: 121)'in Erzurum'da 
yaptıkları araştırmada, işgörenlerin, psikolojik sözleşme ve örgütsel bağlılık alg1 seviyeleri arasında pozitif ve yüksek düzeyde anlamlı bir ilişki olduğu saptanmıştır.

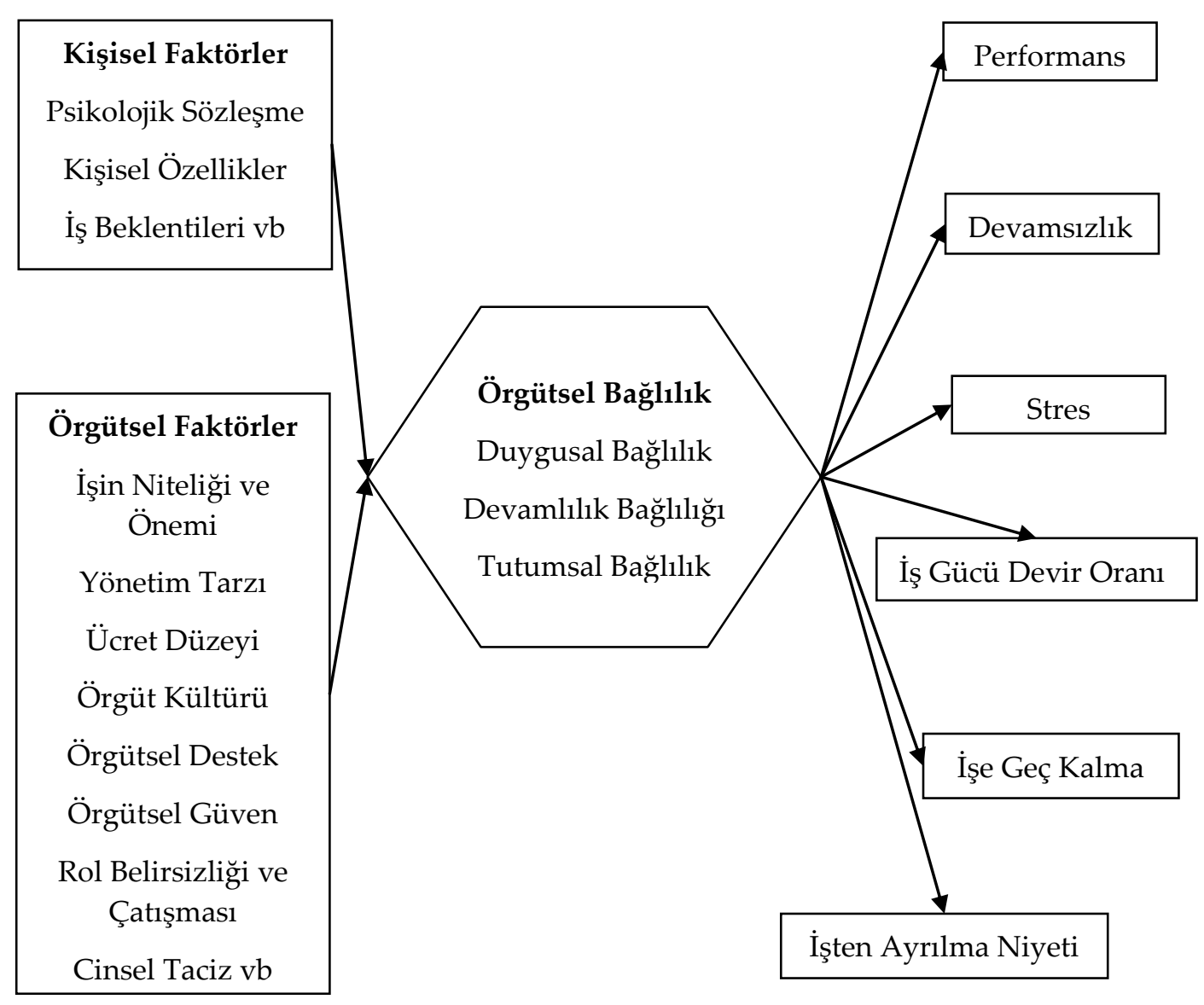

Şekil 1. Örgütsel Bağlılığı Etkileyen Faktörler ve Sonuçları

Kaynak: Yüceler, A. (2009). Örgütsel Bağlllık ve Örgüt İklimi İlişkisi: Teorik ve Uygulamalı Bir Çalışma, Selçuk Üniversitesi S.B.E. Dergisi, s.450.

İşyeri yönetimi veya yönetici davranışları üzerine yapılan araştırmalar, liderin davranış ve uygulamalarının, işgörenlerin örgütsel bağlılıklarını etkilediğini ortaya koymaktadır (Dick ve Metcalfe, 2001:115). Yavuz ve Tokmak (2009: 17), 1lımlı ve etkileşimci liderlik davranışının örgütsel bağlılığı arttırdığını ortaya koymuşlardır.

Çavuş ve Gürdoğan (2008: 18)'ın, örgüt kültürü ve örgütsel bağlılık ilişkisini belirlemeye yönelik olarak beş yıldızlı bir otel işletmesinde yaptıkları araştırmada, örgütsel bağlılık boyutlarından normatif bağl1lığın duygusal ve devam bağlılığına göre daha güçlü olduğu, örgütsel bağlıllk boyutları ile örgüt kültürünün sosyalleşme / örgütsel yapı, semboller / katılım / ödül ve hoşgörü / adalet / işgören seçimi boyutları arasında pozitif ancak zayıf bir ilişki bulunduğu saptanmıştır. 
İşgörenlerin, kendilerini güvende hissetmeleri ve örgütün yanlarında olduğunu bilmeleri şeklinde açıklanan örgütsel destek, çalışanların örgüte bağlilıklarının artmasında önemli bir yönetimsel araçtır. Özdevecioğlu (2003: 113)'nun, Kayseri'de faaliyet gösteren mobilya işletmelerinde çalışan işgörenlerin, destek algılamaları ile bağlılık düzeyleri arasındaki ilişkinin varlığını ortaya koymak amacıyla yaptığı araştırmaya göre; örgütsel bağlılık ile algılanan örgütsel destek arasında pozitif yönlü bir ilişki tespit edilmiştir.

Yıldız ve arkadaşları (2013: 85)'nın, psikolojik taciz ve örgütsel bağlılı̆̆ın sağlık çalışanlarının sosyo-demografik özelliklerine göre farklılaşıp farklılaşmadığını ve psikolojik taciz ile örgütsel bağlılık arasında bir ilişki olup olmadığını belirlemek amacıyla yaptıkları araştırmada sağlık çalışanlarının \%5,2'sinin psikolojik tacize maruz kaldıkları saptanmıştır. Çalışmada psikolojik taciz ve örgütsel bağlılık arasında istatistiksel açıdan ters yönde anlamlı bir ilişki olduğu ve psikolojik taciz davranışlarındaki artışın örgütsel bağlılığın azalmasına neden olduğu tespit edilmiştir.

\section{YÖNTEM}

Batı Karadeniz Bölümünde faaliyet gösteren kapalı ve açık olmak üzere toplam 6 Ceza İnfaz Kurumunda (Karabük -Merkez ve Eskipazar ilçesi-, Bartın, Kastamonu, Bolu, Zonguldak Ceza infaz kurumları) infaz koruma memurları üzerinde gerçekleştirilen bu araştırmada kapalı ve açı ceza infaz kurumları memurlarının iş doyum düzeyleri ile örgütsel bağlılık durumları (devam bağlılığı, tutumsal bağlılık ve duygusal bağlılık) ve ikisi arasındaki olası ilişkinin belirlenmesi amaçlanmaktadır.

Araştırmanın yapıldığı dönemde, Ceza İnfaz Kurumlarında 919 kişinin çalıştığ belirlenmiş olup ana kütleyi temsil eden 524 kişiye anket uygulanmış ve bu anketlerin tamamı değerlendirmeye alınmıştır. Araştırma, Nisan-Mayıs 2014 döneminde gerçekleştirilmiştir. Araştırma kapsamında katılımcılara toplam 29 soru sorulmuştur. Çalışmada işgörenlerin iş doyum düzeylerini belirlemek amacıyla Minnesota İş Tatmin Ölçeği (Minnesota Satisfaction Questionnaire-MSQ) ve örgütsel bağlılık düzeyini ölçmek amacıyla Cook ve Wall'un Örgütsel Bağlllık Ölçeği (Organizational Commitment Instrument-OCI) kullanılmıştır. Bu kapsamda anket, üç bölümden oluşmuştur. İlk bölümde cevaplayıcıların demografik nitelikleri ile çalıştıkları kurumun özelliklerini belirlemeye yönelik sorular yöneltilmiştir. İkinci bölümde, Minesota İş Tatmini Ölçeği'ne ilişkin 18 önerme yer almaktır. Minnesota İş Tatmin Ölçeği (Minnesota Satisfaction Questionnaire-MSQ), Weiss ve arkadaşları tarafından 1967 yılında geliştirilmiştir (Yazıcıoğlu ve Sökmen, 2007: 79). Anketin üçüncü bölümünde ise, katılımcıların örgütsel bağlılık düzeylerine ilişkin 11 önerme içeren Cook ve Wall Örgütsel Bă̆lılık Ölçeği bulunmaktadır. Porter ve arkadaşlarının (1960) ölçeğini temel alan Cook ve Wall ölçeği yaş, çalışma kıdemi, cinsiyet gibi değişkenleri de göz önünde bulundurarak, tutumsal, duygusal ve devam bağılılığ1 gibi örgütsel bağlılık boyutlarını ayırt edebilmektedir (Cook ve Wall, 1980: 39-52). Anket soruları; katılımcıların iş doyumu ve örgütsel bağlılık önermelerine katılım derecesini ölçmek amacıyla 5'li Likert ölçeğinde hazırlanmış olup cevaplayıcılardan en uygun olan seçeneği işaretlemeleri istenmiştir. Bu bağlamda Minnesota Ölçeğinde 1- Hiç Hoşnut 
Değilim, 5- Çok Hoşnutum ve Cook ile Wall ölçeğinde ise 1-Kesinlikle Hayır, 5Kesinlikle Evet'i ifade etmektedir.

Anketten elde edilen veriler, sosyal bilimler istatistik paket programı kullanılarak analiz edilmiştir. Bu kapsamda ilk olarak araştırma örnekleminin demografik özellikleri ile araştırma yapılan Ceza İnfaz Kurumlarının özelliklerinin frekans ve yüzde dağılımları tespit edilmiştir. İkinci aşamada, iş doyumu ve örgütsel bağlılıkla ilgili önermelerin aritmetik ortalama ve standart sapma değerleri analiz edilmiştir. Üçüncü aşamada, iki örneklem gurubu arasında ortalamalar açısından fark olup olmadığını belirlemek amacıyla "t testi" ve ikiden çok örneklem arasında ortalamalar açısından fark olup olmadığını tespit etmek amacıyla "Anova Testi" uygulanmıştır. Dördüncü aşamada ise, iki değişken arasındaki doğrusal ilişkiyi veya bir değişkenin iki veya daha fazla değişken ile olan ilişkisini test etmek için, varsa bu ilişkinin derecesini ölçmeye yarayan korelasyon analizi yapılmıştır.

\section{BULGULAR}

Ankette yer alan iş doyumu ve örgütsel bağlllıkla ilgili önermelerin güvenilirliği "Cronbach Alpha" yöntemi ile ölçülmüştür. Cronbach Alpha; ölçekte kullanılan ifadelerin homojen yapı gösteren bir bütünü ifade edip etmediğini belirleyen bir değerdir. Alfa katsayısından hareketle ölçeğin güvenilirliğini Tablo 1'deki gibi yorumlamak mümkündür (Kalayc1, 2010: 405):

Tablo 1. Cronbach Alpha Güvenilirlik Katsayısı Aralıkları

\begin{tabular}{|l|l|}
\hline Güvenilir Değildir. & $0,00 \leq \alpha<0,40$ \\
\hline Güvenilirlik Düşüktür. & $0,40 \leq \alpha<0,60$ \\
\hline Oldukça Güvenilirdir. & $0,60 \leq \alpha<0,80$ \\
\hline Güvenilirlik Yüksektir. & $0,80 \leq \alpha<1,00$ \\
\hline
\end{tabular}

Batı Karadeniz Bölümünde bulunan Ceza İnfaz Kurumlarında uygulanan iş doyumu ve örgütsel bağlılık önermelerine ilişkin ölçeğin güvenilirlik analizleri Tablo 2 'de yer almaktadır.

Tablo 2. Güvenilirlik Analizine Yönelik Bulguları

\begin{tabular}{|l|c|c|}
\hline & Soru Sayısı & Güvenilirlik Katsayısı $(\boldsymbol{\alpha})$ \\
\hline İş Doyumu & 18 Adet & 0,909 \\
\hline Örgütsel Bağlılık & 11 Adet & 0,699 \\
\hline
\end{tabular}

Tablo 2'deki analiz sonuçlarına göre; araştırma örneklemini oluşturan Ceza İnfaz Kurumlarındaki infaz koruma memurlarının iş doyumuna ilişkin önermelere verdikleri cevapların güvenilirlik katsayının $(\alpha=0,909)$ yüksek güvenilirlikte olduğu belirlenmiştir. Bununla birlikte örgütsel bağlılığa ilişkin önermelere verilen cevapların güvenilirlik katsayısının da $(\alpha=0,699)$ oldukça güvenilir olduğu saptanmıştır. Bu sonuçlar ışığında yapılan alan araştırmasında kullanılan iş doyumu ve örgütsel bağlılık ölçeklerinin güvenilir olduğunu söylemek mümkündür. 


\subsection{Fonksiyonel Değişkenlere Yönelik Bulgular}

Ankete katılanların iş doyumu ve örgütsel bağlılık ile ilgili önermelere katılıp katılmama düzeyleri 5'li Likert ölçeğinde değerlendirilmeye çalışılmıştır.

Tablo 3. İş Doyumuna Yönelik Bulgular

\begin{tabular}{|l|c|c|}
\hline \multicolumn{1}{|c|}{ İ̧̧ DOYUMU } & $\begin{array}{c}\text { Aritmetik } \\
\text { ortalama } \\
\mathbf{( X )}\end{array}$ & $\begin{array}{c}\text { Standart } \\
\text { Sapma } \\
\text { (s.s.) }\end{array}$ \\
\hline 1. Beni her zaman meşgul etmesi bakımından & 2,673 & 1,175 \\
\hline 2. Tek başıma çalışma imkânım olması açısından & 2,534 & 1,199 \\
\hline 3. Ara sıra değişik şeyler yapabilme şansımın olması bakımından & 2,793 & 1,236 \\
\hline 4. Toplumda "saygın bir kişi” olma şansını bana vermesi açısından & 2,496 & 1,355 \\
\hline $\begin{array}{l}\text { 5. Vicdanıma aykırı olmayan şeyleri yapabilme şansım olması } \\
\text { bakımından }\end{array}$ & 2,912 & 1,259 \\
\hline $\begin{array}{l}\text { 6. Bana sabit iş sağlaması bakımından } \\
\text { 7. Başkaları için bir şeyler yapabilme imkânına sahip olmam } \\
\text { bakımından }\end{array}$ & 3,696 & 1,110 \\
\hline $\begin{array}{l}\text { 8. Kendi yeteneklerimi kullanarak bir şeyler yapabilme şansımın } \\
\text { olması bakımından }\end{array}$ & 2,842 & 1,298 \\
\hline 9. İşile ilgili alınan kararların uygulanmaya konması açısından & 2,624 & 1,239 \\
\hline 10. Yaptığım iş karşılığında aldığım ücret bakımdan & 2,595 & 1,323 \\
\hline 11. İş içinde yükselme imkanının olması bakımından & 2,589 & 1,328 \\
\hline $\begin{array}{l}\text { 12. Kendi kararlarımın uygulama serbestliğini bana vermesi } \\
\text { bakımından }\end{array}$ & 2,345 & 1,215 \\
\hline $\begin{array}{l}\text { 13. İşimi yaparken kendi yeteneklerimi kullanabilme şansını bana } \\
\text { sağlaması bakımından }\end{array}$ & 2,559 & 1,251 \\
\hline 14. Çalışma şartları bakımından şansına sahip & 2,257 & 1,235 \\
\hline 15. Çalışma arkadaşlarımın birbirleri ile anlaşması bakımından & 3,091 & 1,253 \\
\hline 16. Yaptığım iyi bir iş karşılığında takdir edilmem açısından & 2,570 & 1,300 \\
\hline 17. Yaptığım iş karşılığında duyduğum başarı hissinden & 3,204 & 1,287 \\
\hline $\begin{array}{l}\text { 18. İş arkadaşlarıma ne yapacaklarını söylemene } \\
\text { olabilmem açısından }\end{array}$ & 1,202 \\
\hline
\end{tabular}

\section{1: Hiç Hoşnut Değilim, 5: Çok Hoşnutum}

Tablo 3'teki sonuçlara göre; katılımcıların, genel olarak çalıştıkları işten elde ettikleri doyumun düşük olduğu görülmektedir. Dolayısıyla infaz koruma memurlarının çalıştıkları işten yeterli doyum elde etmedikleri söylenebilir.

Araştırmada iş doyumu ile ilgili katılım düzeyi en yüksek olan önerme "Bana sabit bir iş sağlaması bakımından işimden memnunum" ( $\bar{X}=3,696$, s.s. $=1,110)$ önermesidir. Bu durum, memurların işlerinden genel anlamda doyum elde 
etmelerinden ziyade, işin güvenli olması yani işten çıkarılma riskinin düşük olması, emeklilik, sosyal güvenlik haklarının bulunması nedenleriyle açıklanabilir. İşsizliğin önemli bir sorun olduğu Türkiye'de sosyal güvenlik sağlayan işler çalışanın meslek ve işyeri seçiminde önem arz etmektedir.

\section{Tablo 4. Örgütsel Bağlılığa Yönelik Bulgular}

\begin{tabular}{|l|c|c|}
\hline \multicolumn{1}{|c|}{ ÖRGÜTSEL BAĞLILIK } & $\begin{array}{c}\text { Aritmeti } \\
\mathbf{k} \\
\text { ortalama } \\
\mathbf{X}\end{array}$ & $\begin{array}{c}\text { Standart } \\
\text { Sapma } \\
\text { (s.s.) }\end{array}$ \\
\hline $\begin{array}{l}\text { 1. Saygın ve güvenilir bir kurum olduğu için iş yerimi başkalarına } \\
\text { söylemekten gurur duyuyorum. }\end{array}$ & 2,513 & 1,311 \\
\hline 2. Daha iyi bir iş bulursam bu iş yerinden ayrılmayı isterim. & 3,858 & 1,214 \\
\hline 3. Sadece iş yerime yararı olsun diye kendimi tüketmeyi istemem. & 3,479 & 1,169 \\
\hline $\begin{array}{l}\text { 4. Kişisel gelişimim destekleyip beni tatmin ettiği için iş yerimi } \\
\text { başkalarına söylemekten gurur duyuyorum. }\end{array}$ & 2,406 & 1,199 \\
\hline 5. Kendimi iş yerimin bir parçası olarak hissediyorum. & 3,167 & 1,237 \\
\hline $\begin{array}{l}\text { 6. İşimde sadece kendim için değil, işim için de çaba harcadığımı } \\
\text { hissetmek isterim. }\end{array}$ & 3,870 & 0,990 \\
\hline $\begin{array}{l}\text { 7. İşimden ayrılarak kazanılmış haklarımı tehlikeye atmak } \\
\text { istemem. }\end{array}$ & 4,005 & 0,978 \\
\hline $\begin{array}{l}\text { 8. İşimin çalıştığım yere katkısı olduğunu bilmek beni memnun } \\
\text { eder. }\end{array}$ & 3,977 & 0,973 \\
\hline $\begin{array}{l}\text { 9. Başka bir işverenden daha fazla ücret teklifi olsa bile, iş } \\
\text { yerimdeki durumumu kaybetmek istemem. }\end{array}$ & 2,687 & 1,282 \\
\hline $\begin{array}{l}\text { 10. İş yerimin karşış̧ı̆ı̆ı zorluklarda, benden beklenenden } \\
\text { fazlasını yapmaya istekli olurum. }\end{array}$ & 3,631 & 1,123 \\
\hline 11. Beni tatmin ettiği sürece işimden ayrılmayı istemem. & 3,660 & 1,253 \\
\hline
\end{tabular}

\section{1: Kesinlikle Hayır, 5: Kesinlikle Evet}

Örgütsel bağlılığa ilişkin Tablo 4'de de görüldüğü üzere; katılımcıların hakkında en olumlu görüş belirttikleri ifadeler, "Daha iyi bir iş bulursam bu iş yerinden ayrılmayı isterim" ( $\bar{X}=3,858$, s.s. $=1,214)$. "İşimden ayrılarak kazanılmış haklarımı tehlikeye atmak istemem" $(\bar{X}=4,005$, s.s. $=0,978)$ önermeleridir. Katılımcıların örgüte yönelik mecburi bağlılıkları şeklinde yorumlanabilecek devamlılık bağlılığındaki bu ifadelere olan katılımların yüksek olması, Türkiye gibi işsizlik oranının yüksek olduğu, iş güvencesinin ve yasal hakların tam anlamıyla sağlanamadığı bir ülkede iş anlamında bir belirsizliğin ve kaygının olması açısından normal olarak yorumlanabilir. Dolayısıyla bu nedenler, devamlılık bağlılığındaki katılım düzeylerinin önemli bir belirleyicisi olarak, katılımların yüksek seviyede çıkmasını sağlayan zemini oluşturmaktadır.

Cevaplayıcıların örgütsel bağlılığın tutumsal boyutuna ilişkin katılım düzeyleri incelendiğinde; "İş yerimin karşılaştı̆̆ı zorluklarda, benden beklenenden fazlasını 
yapmaya istekli olurum" ( $\bar{X}=3,631$, s.s. $=1,123)$ ve "Beni tatmin ettiği sürece işimden ayrılmayı istemem" ( $\bar{X}=3,660$, s.s. $=1,253)$ önermelerine katılımın diğer önermelere oranla daha yüksek olduğu görülmektedir. Tutumsal bağlılık boyutundaki bu sonuçlar, işgörenlerin çalışmakta oldukları kuruma yönelik bir tür vefa tutumu ve bağ lılığı içerisinde olduklarını göstermektedir.

Tablo incelendiğinde örgütsel bağlılığın duygusal boyutuna ilişkin "İşimin çalıştığım yere katkısı olduğunu bilmek beni memnun eder" $(\bar{X}=3,977$, s.s. $=0,973)$ ve "İşimde sadece kendim için değil, işim için de çaba harcadığımı hissetmek isterim" ( $\bar{X}$ $=3,870$, s.s. $=0,990)$ önermelere katılımın daha yüksek olduğu görülmektedir. Duygusal bağlılık boyutundaki bu ifadelere olan katılımların yüksek düzeyde olması, katılımcıların çalıştıkları kurumu benimsedikleri ve kendileriyle özdeşleştirdikleri, sonuçta da işgörenlerin bulundukları kurumla ortak bir amaç ve kaygı paydasında buluştukları şeklinde yorumlanabilir.

\subsection{Fonksiyonel Değişkenlerin Demografik ve Kurum Değişkenleriyle Karşıllaştırılması}

Araştırmanın bu kısmında; iş doyumu ile örgütsel bağlılığın alt boyutları olan tutumsal, devamlılık ve duygusal bağlılığın araştırmaya katılan kişilerin demografik özellikleri ve çalıştıkları kurum özelliklerine göre farklılaşıp farklılaşmadığını belirlemek amacıyla uygulanan $t$ ve Anova testleri sonuçları incelenmiştir. Tablo 5 'te iş doyumunun, araştırmaya katılan kişilerin demografik özelliklerine göre anlamlı bir farklılaşma gösterip göstermediğini belirlemek amacıyla uygulanan "t ve Anova Testi" sonuçları bulunmaktadır. 
Tablo 5. İş Doyumunun Tanımlayıcı Bilgilere Göre Dağılımı

\begin{tabular}{|c|c|c|c|c|c|c|c|}
\hline \multicolumn{2}{|l|}{ Değişkenler } & \multirow{2}{*}{$\begin{array}{l}\mathbf{n} \\
47\end{array}$} & \multirow{2}{*}{\begin{tabular}{|c|}
$\bar{X}$ \\
2,757
\end{tabular}} & \multirow{2}{*}{$\begin{array}{c}\text { s.s. } \\
0,818\end{array}$} & \multirow{3}{*}{$\frac{\mathbf{F}}{0,002}$} & \multirow{3}{*}{$\frac{\mathbf{p}}{0,809}$} & \multirow[t]{3}{*}{ Tukey } \\
\hline \multirow{2}{*}{ Cinsiyet } & a. Kadın & & & & & & \\
\hline & b. Erkek & 477 & 2,786 & 0,781 & & & \\
\hline \multirow{5}{*}{ Yaş } & a. $18-25$ & 84 & 2,795 & 0,686 & \multirow{5}{*}{0,535} & \multirow{5}{*}{0,710} & \\
\hline & b. 26-35 & 224 & 2,802 & 0,771 & & & \\
\hline & c. $36-45$ & 72 & 2,708 & 0,771 & & & \\
\hline & d. $46-55$ & 129 & 2,810 & 0,870 & & & \\
\hline & e. 56 ve Üstü & 15 & 2,563 & 0,794 & & & \\
\hline \multirow{3}{*}{ Medeni Durum } & a. Evli & 331 & 2,760 & 0,771 & \multirow{3}{*}{1,078} & \multirow{3}{*}{0,341} & \\
\hline & b. Bekar & 184 & 2,808 & 0,817 & & & \\
\hline & c. Boşanmış & 9 & 3,123 & 0,410 & & & \\
\hline \multirow{4}{*}{$\begin{array}{l}\text { Eğitim } \\
\text { Durumu }\end{array}$} & a. İlköğretim & 18 & 3,034 & 0,942 & \multirow{4}{*}{0,766} & \multirow{4}{*}{0,514} & \\
\hline & b. Lise & 201 & 2,789 & 0,780 & & & \\
\hline & c. Üniversite & 298 & 2,768 & 0,777 & & & \\
\hline & d. Y. Lisans & 7 & 2,611 & 0,756 & & & \\
\hline \multirow{2}{*}{ Çalışma Şekli } & a. Gündüz & 273 & 2,925 & 0,794 & \multirow{2}{*}{0,911} & \multirow{2}{*}{$0,000^{*}$} & \multirow{2}{*}{$a>b$} \\
\hline & b. Vardiyalı & 251 & 2,628 & 0,743 & & & \\
\hline \multirow{7}{*}{ Hizmet Süresi } & a. 1 Yildan $\mathrm{Az}$ & 49 & 3,296 & 0,714 & \multirow{6}{*}{5,118} & \multirow{6}{*}{$0,000^{*}$} & \multirow{6}{*}{$a>b, f$} \\
\hline & b. 1-5 Yil & 220 & 2,739 & 0,718 & & & \\
\hline & c. $6-10 Y_{11}$ & 63 & 2,650 & 0,741 & & & \\
\hline & d. 11-15 Y11 & 20 & 2,609 & 1,046 & & & \\
\hline & e. $16-20 Y_{11}$ & 39 & 2,740 & 0,746 & & & \\
\hline & f. $20 Y_{11}$ Üstü & 133 & 2,768 & 0,838 & & & \\
\hline & TOPLAM & 524 & & & & & \\
\hline
\end{tabular}

${ }^{*} \mathbf{p}<0,05$

Tablo 5'daki sonuçlar değerlendirildiğinde; katılımcıların cinsiyet, yaş, medeni durum ve eğitim durumları ile iş doyumu ortalaması anlamında birbirine yakın değerlere sahip oldukları görülmektedir. Bu sonuçlar ışığında, Batı Karadeniz Bölümünde faaliyet gösteren ceza infaz kurumlarında çalışan erkek ve kadın işgörenlerin işle ilgili doyum düzeylerinin farklılık göstermediği söylenebilir. Benzer biçimde eğitim durumu, medeni durum cinsiyet ve yaş ile iş doyum düzeyi arasında bir farklılık bulunmamaktadır. Araştırmaya katılan çalışanların iş doyumu açısından gündüz ya da vardiyalı olarak çalışması $(F=0,911, p=0,000)$ arasında $p<0,05$ anlamlılık düzeyinde bir farklılık olduğu görülmektedir. Gündüz çalışan memurlar vardiyalı çalışanlara göre daha yüksek bir iş doyumuna sahiptir. Bunun yanı sıra işgörenlerin iş doyumlarının hizmet süresi bağlamında da farklılık gösterdiği görülmektedir. 1 yıldan daha az çalışan işgörenlerin $(F=5,118, p=0,000) p<0,05$ anlamlılık düzeyinde, 1-5 yıl arası ile 20 yılın üzerinde çalışan işgörenlerden daha fazla işlerinden doyum elde ettikleri görülmektedir. 
Tablo 6 iş doyumunun, araştırmaya katılan kişilerin çalıştıkları kurum değişkenlerine göre anlamlı bir farklılaşma gösterip göstermediğini belirlemek amacıyla uygulanan "t ve Anova Testi" sonuçlarını göstermektedir.

Tablo 6. İş Doyumunun Kurum Değişkenlerine Göre Dağılımı

\begin{tabular}{|c|c|c|c|c|c|c|c|}
\hline \multicolumn{2}{|l|}{ Değişkenler } & \multirow{2}{*}{$\begin{array}{l}\mathbf{n} \\
450 \\
\end{array}$} & \multirow{2}{*}{$\begin{array}{c}\bar{X} \\
2,783 \\
\end{array}$} & \multirow{2}{*}{$\begin{array}{c}\text { s.s. } \\
0,788\end{array}$} & \multirow{3}{*}{$\frac{\mathbf{F}}{0,366}$} & \multirow{3}{*}{$\begin{array}{c}\mathbf{P} \\
0,987\end{array}$} & \multirow[t]{3}{*}{ Tukey } \\
\hline \multirow{2}{*}{$\begin{array}{l}\text { Ceza İnfaz } \\
\text { Kurumu Tipi }\end{array}$} & a. Kapalı & & & & & & \\
\hline & b. Açık & 74 & 2,784 & 0,762 & & & \\
\hline \multirow{7}{*}{$\begin{array}{l}\text { Ceza İnfaz } \\
\text { Kurumunun } \\
\text { Bulunduğu Yer }\end{array}$} & a. Karabük & 142 & 2,551 & 0,692 & \multirow{6}{*}{10,358} & \multirow{6}{*}{$0,000^{*}$} & \multirow{6}{*}{$\begin{array}{c}c>b \\
d>a, b, e \\
f>a, b, e\end{array}$} \\
\hline & b. Bartın & 48 & 2,427 & 0,822 & & & \\
\hline & c. Kastamonu & 103 & 2,825 & 0,759 & & & \\
\hline & d. Bolu & 100 & 3,055 & 0,771 & & & \\
\hline & e. Eskipazar & 25 & 2,511 & 0,896 & & & \\
\hline & f. Zonguldak & 106 & 3,022 & 0,728 & & & \\
\hline & TOPLAM & 524 & & & & & \\
\hline
\end{tabular}

${ }^{*} \mathrm{p}<0,05$

İş doyumunun ceza infaz kurumlarının tipi ve bulunduğu yerlere göre dağılımına ilişkin tablo 6 incelendiğinde; Kastamonu ile Bartın, Bolu ile Karabük, Bartın ve Eskipazar ve Zonguldak ile Karabük, Bartın, Eskipazar kurumlarında çalışan işgörenlerin ( $F=10,358, p=0,000)$ iş doyum düzeyleri arasında $p<0,05$ anlamlılık düzeyinde bir farklılık olduğu görülmektedir. Kastamonu ile Bartın arasındaki farklılığın, Kastamonu'da bulunan ceza infaz kurumunun daha eski bir geçmişe sahip olması, şehir merkezine yakın olması ve kurumda çalışanların sosyal ilişkiler konusunda daha yüksek avantajlara sahip olmasından kaynaklandığı söylenebilir. Tablo incelendiğinde; Bolu ve Zonguldak illerindeki kurumlarda çalışan koruma memurlarının iş doyum düzeylerinin diğer yerlere göre daha yüksek çıktığ 1 görülmektedir. Bolu ve Zonguldak illerinde çalışanların iş doyum düzeylerinin daha yüksek çıkmasının nedenini, kurumsallaşmış bir alt yapısının olması, daha köklü bir geçmişe sahip olmaları, işgörenlerin daha iyi çalışma ortamına sahip olmaları ve sosyal ilişkiler konusunda daha olumlu şartlara sahip olmalarına bağlamak mümkündür.

Bulgular, ceza infaz koruma memurlarının; örgütsel bağlllığın alt boyutları olan duygusal, devamlılık ve tutumsal bağlllıklarının cinsiyet faktörüne göre istatistiki anlamda farklılaşmadığını göstermektedir. Benzer şekilde duygusal, devamlılık ve tutumsal bağlılık, yaş ve eğitim durumu faktörlerine göre de farklılaşmamaktadır.

Tablo 7'de örgütsel bağlılık alt boyutlarının, araştırmaya katılan kişilerin medeni durumlarına göre anlamlı bir farklılık gösterip göstermediğini belirlemek amacıyla uygulanan "Anova Testi" sonuçları yer almaktadır. 
Tablo 7. Örgütsel Bağlılık Alt Boyutlarının Medeni Duruma Göre Dağılımı

\begin{tabular}{|c|c|c|c|c|c|c|c|}
\hline \multicolumn{2}{|c|}{ Medeni Durum } & $\mathbf{n}$ & $\bar{X}$ & s.s. & $\mathbf{F}$ & $\mathbf{P}$ & Tukey \\
\hline \multirow{3}{*}{$\begin{array}{l}\text { Tutumsal } \\
\text { Bağlllık }\end{array}$} & a. Evli & 331 & 3,289 & 0,692 & \multirow{3}{*}{2,163} & \multirow{3}{*}{0,116} & \\
\hline & b. Bekar & 184 & 3,326 & 0,702 & & & \\
\hline & c. Boşanmış & 9 & 2,833 & 0,800 & & & \\
\hline \multirow{3}{*}{$\begin{array}{l}\text { Devam } \\
\text { Bağl1lı̆̆} 1\end{array}$} & a. Evli & 331 & 3,550 & 0,635 & \multirow{3}{*}{1,269} & \multirow{3}{*}{0,282} & \\
\hline & b. Bekar & 184 & 3,456 & 0,655 & & & \\
\hline & c. Boşanmiş & 9 & 3,518 & 0,709 & & & \\
\hline \multirow{4}{*}{$\begin{array}{l}\text { Duygusal } \\
\text { Bağlılık }\end{array}$} & a. Evli & 331 & 3,413 & 0,755 & \multirow{3}{*}{3,837} & \multirow{3}{*}{$0,022^{*}$} & \multirow{3}{*}{$\begin{array}{l}a>c \\
b>c\end{array}$} \\
\hline & b. Bekar & 184 & 3,358 & 0,818 & & & \\
\hline & c. Boşanmış & 9 & 2,694 & 0,966 & & & \\
\hline & TOPLAM & 524 & & & & & \\
\hline
\end{tabular}

Araştırmaya katılan işgörenlerin; devamlılık ve tutumsal bağlılık boyutları medeni durumlarına göre farklılaşma göstermemektedir. Bununla birlikte medeni durum ile duygusal bağlılık boyutu arasında $(\mathrm{F}=3,837, \mathrm{p}=0,022) \mathrm{p}<0,05$ anlamlılık düzeyinde bir farklılık olduğu saptanmıştır. Bu sonucun ortaya çıkmasında, evli işgörenlerin, Türk aile yapısı gereği ailevi sorumluluklarının daha yüksek olmasının ve evi geçindirme yükünü daha çok hissetmelerinin etken olduğu söylenebilir. Dolayısıyla işgörenlerin bu yükün üstesinden gelme olanağını sağlayan kurumlara yönelik olarak geliştirdikleri bir tür vefa görevi gereği örgütsel bağlılıklarının daha yüksek olduğunu söylemek mümkündür. Bekâr ve boşanmış işgörenler arasındaki duygusal bağlılık farklılığının nedeni ise; boşanmış işgörenlerin sosyolojik ve psikolojik yönden daha olumsuz etkiler altında kalmaları olabilir.

Tablo 8'da örgütsel bağlılık alt boyutlarının, araştırmaya katılan kişilerin hizmet sürelerine göre anlamlı bir farklılaşma gösterip göstermediğini belirlemek amacıyla uygulanan "Anova Testi" sonuçları yer almaktadır. 
Tablo 8. Örgütsel Bağlılık Boyutlarının Hizmet Süresine Göre Dağılımı

\begin{tabular}{|c|c|c|c|c|c|c|c|}
\hline \multicolumn{2}{|c|}{ Hizmet Süresi } & $\mathbf{n}$ & $\bar{X}$ & s.s. & $\mathbf{F}$ & $\mathbf{P}$ & \multirow[t]{7}{*}{ Tukey } \\
\hline \multirow{6}{*}{$\begin{array}{l}\text { Tutumsal } \\
\text { Bağlllık }\end{array}$} & a. 1 Yildan Az & 49 & 3,505 & 0,656 & \multirow{6}{*}{1,614} & \multirow{6}{*}{0,154} & \\
\hline & b. $1-5 Y_{11}$ & 220 & 3,314 & 0,687 & & & \\
\hline & c. $6-10 Y_{1} 1$ & 63 & 3,234 & 0,719 & & & \\
\hline & d. 11-15 Yil & 20 & 3,412 & 0,900 & & & \\
\hline & e. $16-20 Y_{11}$ & 39 & 3,262 & 0,643 & & & \\
\hline & f. 20 Yil Üstü & 133 & 3,203 & 0,697 & & & \\
\hline \multirow{6}{*}{$\begin{array}{l}\text { Devam } \\
\text { Bağlılığı }\end{array}$} & a. 1 Yildan $\mathrm{Az}$ & 49 & 3,340 & 0,682 & \multirow{6}{*}{1,094} & \multirow{6}{*}{0,363} & \\
\hline & b. 1-5 Yil & 220 & 3,537 & 0,569 & & & \\
\hline & c. $6-10 Y_{11}$ & 63 & 3,608 & 0,702 & & & \\
\hline & d. 11-15 Yil & 20 & 3,533 & 0,812 & & & \\
\hline & e. $16-20 Y_{11}$ & 39 & 3,547 & 0,609 & & & \\
\hline & f. 20 Yil Üstü & 133 & 3,493 & 0,698 & & & \\
\hline \multirow{7}{*}{$\begin{array}{c}\text { Duygusal } \\
\text { Bağl1lık }\end{array}$} & a. 1 Yildan Az & 49 & 3,739 & 0,765 & \multirow{6}{*}{3,172} & \multirow{6}{*}{$0,008^{*}$} & \multirow{6}{*}{$a>b, c$} \\
\hline & b. 1-5 Yil & 220 & 3,297 & 0,777 & & & \\
\hline & c. $6-10 Y_{11}$ & 63 & 3,265 & 0,739 & & & \\
\hline & d. 11-15 Yil & 20 & 3,350 & 1,036 & & & \\
\hline & e. $16-20 Y_{11}$ & 39 & 3,525 & 0,751 & & & \\
\hline & f. 20 Y$_{11}$ Üstü & 133 & 3,407 & 0,765 & & & \\
\hline & TOPLAM & 524 & & & & & \\
\hline
\end{tabular}

Tablo 8 incelendiğinde; örgütsel bağlılığın alt boyutları olan tutumsal ve devam bağlılıklarında hizmet süresine göre anlamlı bir farklılaşma olmadı̆̆ı saptanmıştır. Bunun yanı sıra örgüsel bağl1lı̆̆ın duygusal boyutu ile hizmet süresi ( $F=3,172, p=$ 0,008 ) arasında $\mathrm{p}<0,05$ anlamlılık düzeyinde bir farklılık olduğu tespit edilmiştir. $\mathrm{Bu}$ sonuçlar çerçevesinde; araştırmaya katılanlardan kurumda çalışma süresi 1-5 ve 6-10 yıl olanların, 1 yıldan kısa bir süredir kurumda çalışan işgörenlere göre örgüte yönelik duygusal bağlılık düzeylerinin daha düşük olduğu söylenebilir.

Tablo 9'da örgütsel bağlılık alt boyutlarının, araştırmaya katılan kişilerin çalışma türü olan gündüz ile vardiyalı çalışma durumlarına göre anlamlı bir farklılaşma gösterip göstermediğini belirlemek amacıyla uygulanan "t Testi" sonuçları yer almaktadır. 
Tablo 9. Örgütsel Bağlılık Alt Boyutlarının Çalışma Şekline Göre Dağılımı

\begin{tabular}{|c|c|c|c|c|c|c|c|}
\hline \multicolumn{2}{|c|}{ Çalışma Şekli } & $\mathbf{n}$ & $\bar{X}$ & s.s. & F & $\mathbf{P}$ & Tukey \\
\hline \multirow{2}{*}{$\begin{array}{c}\text { Tutumsal } \\
\text { Bağlılık }\end{array}$} & a. Gündüz & 273 & 3,389 & 0,677 & \multirow{2}{*}{1,001} & \multirow{2}{*}{$0,001^{*}$} & \multirow{2}{*}{$a>b$} \\
\hline & b. Vardiyalı & 251 & 3,191 & 0,709 & & & \\
\hline \multirow{2}{*}{$\begin{array}{c}\text { Devam } \\
\text { Bağlılığ1 }\end{array}$} & a. Gündüz & 273 & 3,559 & 0,662 & \multirow{2}{*}{0,186} & \multirow{2}{*}{0,119} & \\
\hline & b. Vardiyalı & 251 & 3,471 & 0,622 & & & \\
\hline \multirow{3}{*}{$\begin{array}{c}\text { Duygusal } \\
\text { Bağlilık }\end{array}$} & a. Gündüz & 273 & 3,524 & 0,737 & \multirow{2}{*}{3,229} & \multirow{2}{*}{$0,000^{*}$} & \multirow{2}{*}{$a>b$} \\
\hline & b. Vardiyalı & 251 & 3,227 & 0,809 & & & \\
\hline & TOPLAM & 524 & & & & & \\
\hline
\end{tabular}

${ }^{*} \mathrm{p}<0,05$

Tablo 9'daki sonuçlara göre; araştırmaya katılan işgörenlerin; örgütsel bağlılığının devamlılık boyutunda bir farklılık gözlenmezken, tutumsal bağlılık boyutunda $(F=1,001, p=0,001)$ ve duygusal bağl1lı boyutunda $(F=3,229, p=0,000) p$ $<0,05$ anlamlılık düzeyinde bir farklılık olduğu saptanmıştır. Örgütsel bağlılığın tutumsal ve duygusal boyutlarının çalışma şekline göre farklılık göstermesinin nedenleri; vardiyalı çalışanların mesai saatlerinin daha uzun olması, uykusuzluk sorunları ve mahkûmla daha fazla birebir ilişki içerisinde bulunmaları olarak siralanabilir.

Tablo 10'da örgütsel bağlılık alt boyutlarının, araştırmaya katılan kişilerin çalıştıkları kurumların bulunduğu yere göre anlamlı bir farklılaşma gösterip göstermediğini belirlemek amacıyla uygulanan "Anova Testi" sonuçları bulunmaktadir. 
Tablo 30. Örgütsel Bağlılık Alt Boyutlarının İnfaz Koruma Kurumunun Bulunduğu Yere Göre Dağılımı

\begin{tabular}{|c|c|c|c|c|c|c|c|}
\hline \multicolumn{2}{|c|}{$\begin{array}{c}\text { Ceza İnfaz Kurumunun } \\
\text { Bulunduğu Yer }\end{array}$} & $\mathbf{n}$ & $\bar{X}$ & s.s. & $\mathbf{F}$ & p & Tukey \\
\hline \multirow{6}{*}{$\begin{array}{l}\text { Tutumsal } \\
\text { Bağlilık }\end{array}$} & a. Karabük & 142 & 3,244 & 0,660 & \multirow{6}{*}{2,596} & \multirow{6}{*}{$0,025^{*}$} & \multirow{6}{*}{$\begin{array}{c}\mathrm{c}>\mathrm{a} \\
\mathrm{d}>\mathrm{a} \\
\mathrm{b}<\mathrm{a}, \mathrm{c}, \mathrm{d} \\
\mathrm{d}>\mathrm{c} \\
\mathrm{f}<\mathrm{a}, \mathrm{c}, \mathrm{d}\end{array}$} \\
\hline & b. Bartın & 48 & 3,187 & 0,619 & & & \\
\hline & c. Kastamonu & 103 & 3,400 & 0,625 & & & \\
\hline & d. Bolu & 100 & 3,440 & 0,621 & & & \\
\hline & e. Eskipazar & 25 & 3,040 & 0,762 & & & \\
\hline & f. Zonguldak & 106 & 3,228 & 0,861 & & & \\
\hline \multirow{6}{*}{$\begin{array}{l}\text { Devam } \\
\text { Bağllilı̆g1 }\end{array}$} & a. Karabük & 142 & 3,537 & 0,577 & \multirow{6}{*}{4,791} & \multirow{6}{*}{$0,000^{*}$} & \multirow{6}{*}{$\begin{array}{l}a>f \\
c>f \\
d>f \\
e>f\end{array}$} \\
\hline & b. Bartın & 48 & 3,555 & 0,572 & & & \\
\hline & c. Kastamonu & 103 & 3,614 & 0,573 & & & \\
\hline & d. Bolu & 100 & 3,563 & 0,507 & & & \\
\hline & e. Eskipazar & 25 & 3,786 & 0,738 & & & \\
\hline & f. Zonguldak & 106 & 3,270 & 0,833 & & & \\
\hline \multirow{7}{*}{$\begin{array}{l}\text { Duygusal } \\
\text { Bağlllık }\end{array}$} & a. Karabük & 142 & 3,130 & 0,802 & \multirow{6}{*}{7,423} & \multirow{6}{*}{$0,000^{*}$} & \multirow{6}{*}{$\begin{array}{l}c>a \\
d>a \\
d>b\end{array}$} \\
\hline & b. Bartın & 48 & 3,239 & 0,695 & & & \\
\hline & c. Kastamonu & 103 & 3,495 & 0,711 & & & \\
\hline & d. Bolu & 100 & 3,695 & 0,632 & & & \\
\hline & e. Eskipazar & 25 & 3,250 & 0,732 & & & \\
\hline & f. Zonguldak & 106 & 3,410 & 0,894 & & & \\
\hline & TOPLAM & 524 & & & & & \\
\hline
\end{tabular}

${ }^{*} \mathrm{p}<0,05$

Örgüsel bağlılık alt boyutlarının kurumun bulunduğu yöreye göre farklılık gösterip göstermediğini gösteren Tablo 10 incelendiğinde; tutumsal bağlılı̆̆ın ( $\mathrm{F}=$ 2,596, $\mathrm{p}=0,025)$, devam bağlilığının $(\mathrm{F}=4,791, \mathrm{p}=0,000)$ ve duygusal bağl1lı̆̆ın $(\mathrm{F}=$ $7,423, \mathrm{p}=0,000)$ ceza infaz kurumunun bulunduğu yere göre $\mathrm{p}<0,05$ anlamlılik düzeyinde farklılık gösterdiği saptanmıştır. Farklılığın hangi şehirdeki cezaevinden kaynaklandığını gösteren Tukey testi incelendiğinde; infaz kurumlarının tutumsal bağlılık boyutuna ilişkin değerlerin birbirine yakın olduğu görülmektedir. Bununla birlikte; Karabük, Bartın, Kastamonu, Bolu ve Eskipazar'daki ceza infaz kurumlarında çalışanların devam bağlılığının Zonguldak'taki ceza infaz kurumunda çalışanlardan daha yüksek olduğu görülmektedir. Bunun yanı sıra duygusal bağlılık ile ilgili değerler incelendiğinde; Kastamonu ve Bolu'daki kurumlarda çalışanların Karabük ilindeki çalışanlara göre, ayrıca Bolu'da çalışanların Bartın ilindeki çalışan infaz koruma memurlarına göre işlerine duygusal bağlılık boyutunda daha fazla bağlı oldukları tespit edilmiştir.

Araştırmaya katılan işgörenlerin, iş doyumu düzeylerinin, örgütsel bağlılık ve alt boyutları ile olan ilişkisini belirlemek amacıyla yapılan Korelasyon testi sonuçları Tablo 12'de görülmektedir. Araştırmada yapılan analizler sonucunda elde edilen 
Korelasyon katsayılarının yorumlanmasında Tablo 11'de belirtilen aralıklar dikkate alınmıştır (Kalaycı, 2010: 116).

Tablo 11. Korelasyon Katsayısı Aralıkları

\begin{tabular}{|l|c|}
\hline Çok Zayıf İlişki & $0,00-0,25$ \\
\hline Zayıf İlişki & $0,26-0,49$ \\
\hline Orta Düzeyde İlişki & $0,50-0,69$ \\
\hline Yüksek Düzeyde İlişki & $0,70-0,89$ \\
\hline Çok Yüksek İlişki & $0,90-1,00$ \\
\hline
\end{tabular}

Tablo 12. İş doyumu ile Örgütsel Bağlılık Düzeyi ve Alt Boyutları Arasındaki İlişki

\begin{tabular}{|c|c|c|c|c|c|}
\hline \multicolumn{2}{|c|}{} & $\begin{array}{c}\text { Genel Örgütsel } \\
\text { Bağll1k }\end{array}$ & $\begin{array}{c}\text { Duygusal } \\
\text { Bağllık }\end{array}$ & $\begin{array}{c}\text { Devamlılık } \\
\text { Bağll1ığ1 }\end{array}$ & $\begin{array}{c}\text { Tutumsal } \\
\text { Bağllık }\end{array}$ \\
\hline \multirow{2}{*}{ İş Doyumu } & $\begin{array}{c}\text { Pearson } \\
\text { Korelasyon }\end{array}$ & 0,541 & 0,592 & 0,189 & 0,440 \\
\cline { 2 - 6 } & $\mathrm{P}$ & $0,000^{* * *}$ & $0,000^{* * *}$ & $0,000^{* * *}$ & $0,000^{* * *}$ \\
\hline
\end{tabular}

*** $\mathrm{p}<0,001$

İş doyumu ile işgörenlerin genel olarak örgütsel bağlıllğ düzeyde, pozitif yönlü $(r=0,541)$ ve anlamlı bir ilişkinin olduğu belirlenmiştir. Bu durum iş doyumunun örgütsel bağlılığı etkilediğini ortaya koymaktadır. Çalışmada iş doyumu ile duygusal bağlllık boyutu arasında orta düzeyde, pozitif yönlü $(r=0,592)$ ve anlamlı bir ilişki; devamlılık bağlılığı arasında çok zayıf düşük, pozitif yönlü ( $\mathrm{r}=$ 0,189 ) ve anlamlı bir ilişki ve tutumsal bağlılık arasında ise, zayıf düzeyde, pozitif yönlü $(r=0,440)$ ve anlamlı bir ilişki olduğu saptanmıştır. Bu durum iş doyumu arttıkça duygusal, devamlılık ve tutumsal bağlılığın arttığını göstermektedir.

\section{SONUÇ}

Örgütlerin sürdürebilirliğinde en etkin kaynak olarak kabul edilen insan kaynağının, örgütsel amaçlar doğrultusunda yönlendirilebilmesi için örgütlerin, işgörenlerinin iş doyumlarını ve örgüte bağlılıklarını artırıcı faaliyetlerde bulunmaları gerekmektedir. İşgörenlerin verimliliklerini artırmada en etkili araçlardan biri olan iş doyumu çalışanın işe yönelik tutumunu yansitır. Bu tutum olumlu olduğunda doyum yüksek, olumsuz olduğunda ise düşüktür. Dolayısıyla örgüt üyelerinin kendilerini örgütün bir parçası gibi hissetmeleri ve örgüte bağlllık duymalarının, işlerinden doyum elde etmelerinin bir sonucu olduğunu söylemek mümkündür. Bu iki olgunun, ceza infaz kurumlarında çalışan infaz koruma memurları açısından incelenmesi amacıyla bu çalışmada iş doyumu ve örgütsel bağlılık arasındaki ilişkinin düzeyi ve yönü belirlenmeye çalışılmış, bu amaçla Batı Karadeniz Bölümünde bulunan ceza infaz kurumlarında ampirik bir çalışma gerçekleştirilmiştir. 
Batı Karadeniz Bölümünde bulunan ceza infaz kurumlarında çalışan 524 infaz koruma memuru üzerinde yapılan çalışmanın sonuçları değerlendirildiğinde; katılımcıların, genel olarak çalıştıkları işten elde ettikleri doyumun düşük olduğu görülmektedir. Dolayısıyla infaz koruma memurlarının çalıştıkları işten yeterince doyum sağlamadıkları söylenebilir. Katılımcıların iş doyumu ile ilgili önermelere katılımlarının düşük düzeyde olması; ceza infaz kurumlarında çalışmanın zor, yorucu ve psikolojik olarak yıpratıcı olması, işin önemli kısmının çeşitli suçlardan ceza almıs, psikolojik olarak sorunlu olabilecek insanlarla iletişim ve etkileşimden oluşması, toplumdan soyutlamak ve tekrar hayata dönünceye kadar rehabilite etmek amaciyla kurumlaşan bir görevden oluşması nedenleriyle olağan karşılanabilir. Dolayısıyla bu zor iş koşullarının iş doyumu ve örgütsel bağlılığı olumsuz etkilemesi kaçınılmazdır.

Katılımcıların demografik değişkenleri (cinsiyet, yaş, medeni durum, eğitim durumu v.b.) dikkate alındığında çalışanların cinsiyet, yaş, medeni durum, eğitim durum ve cezaevi tipine göre işten elde ettikleri doyum düzeylerinin farklılık göstermediği görülmektedir. Benzer bir sonuç İlgün'ün (2010) infaz koruma memurlarının iş doyum düzeylerini belirlemek amacıyla yaptığ 1 çalışmada da ortaya çıkmış, araştırmacı cinsiyet ve yaşa göre çalışanların işten elde ettikleri doyum düzeylerinin farklılık göstermediğini saptamıştır. Kartal (2012), demografik değişkenlerin iş doyumuna olan etkisini tespit etmek amacıyla yaptığı araştırmada, iş doyumu ile cinsiyet değişkeni arasında anlamlı bir ilişki olmadığı sonucunu ortaya koymuştur. Yapraklı ve Yılmaz (2007), demografik özellikler ile motivasyon ve iş doyumu arasındaki ilişkiyi belirlemek amacıyla yaptığı araştırmada, eğitim düzeyi ile iş doyumu arasında pozitif yönlü bir ilişki bulmuş, eğitim düzeyi arttıkça çalışma şartlarından duyulan doyumun da arttığını tespit etmiştir.

Araştırmaya katılan çalışanların çalışma şekli (gündüz ya da vardiyalı çalışma) dikkate alındığında çalışma şekli ile iş doyumu arasında bir farklılık olduğu görülmüştür. Ceza infaz Kurumlarında vardiyalı olarak çalışanlar, gündüz çalışanlara kıyasla daha az göz önünde olduklarından ve yönetimle yeterince iletişim kuramadıklarından yaşadıkları sıkıntıların, problemlerin veya başarılarının yönetim tarafından yeterince dikkate alınmadığına inanmaktadırlar. Ayrıca vardiyalı çalışanların mahkûmla daha çok iletişim içinde olmaları, mahkûmla yaşanan olumsuz durumlar ve çatışma nedeni ile daha çok idari ve adli soruşturma geçirmelerine, ifade ve mahkemeye gitmelerinin yaratmış olduğu strese bağlı olarak daha çok psikolojik sorun yaşamalarına neden olmakta, bu durum vardiyalı çalışanların iş doyum düzeylerini de olumsuz biçimde etkilemektedir.

Memurların iş doyumlarının hizmet süresi bağlamında da farklılık gösterdiği görülmektedir. Kurumda 1 yıldan daha az çalışan işgörenlerin işlerinden 1-5 yıl arası ile 20 yılın üzerinde çalışan işgörenlerden daha fazla doyum elde ettikleri görülmektedir. Bunun sebeplerinden biri, işgörenin iş ile ilgili sıkıntıların işe başladığı ilk dönemlerde daha rahat üstesinden gelmesi ilerleyen dönemlerde ise iş ile ilgili sıkıntıların ve zorlukların artmasıyla bu durumun çalışanda stres yaratması ve bunun sonucu olarak ortaya çıkan psikolojik rahatsızlıklar olabilir. Bu sonuç, Tor'un (2011) hizmet süresi az olanların işlerinden daha fazla doyum elde ettikleri bulgusu ile 
paralellik göstermektedir. Ancak Lamb’ın (1993) mesleki deneyimi az olan öğretmenlerin iş doyum düzeylerinin de düşük olduğu bulgusunu desteklememektedir (Akt. Taşdan ve Tiryaki, 2008: 58).

Araştırmada iş doyumunun çalışılan kurumun bulunduğu yere göre farklılık gösterdiği saptanmıştır. İş doyumunun ceza infaz kurumlarının bulunduğu yerlere göre dağılımı incelendiğinde; Kastamonu ile Bolu, Bolu ile Karabük, Bartın ile Eskipazar ve Zonguldak ile Karabük, Bartın, Eskipazar kurumlarında çalışan işgörenlerin iş doyum düzeyleri arasında farklılık saptanmıştır.

Örgütsel bağlılığa ilişkin önermelere katılım düzeyleri incelendiğinde; katılımcıların daha iyi bir iş bulduklarında işlerini bırakmaya meyilli oldukları görülmektedir. Bunun nedeni, ceza infaz kurumları çalışanlarının diş iletişime kapalı bir ortamda görev yapmaları ve birçok suçlunun bir arada bulunmasından kaynaklanan sıkıntılar ile mahkûmların rehabilite edilmesinde ortaya çıkan zorluklar olabilir. Ayrıca infaz koruma memurluğu mesleğinin diğer mesleklere göre iyi bir iş olarak algılanmamasi, medyada ceza infaz kurumlarına ve infaz koruma memurlarına yönelik olarak çeşitli dizilerin de etkisiyle ortaya çıkan olumsuz algılar ve önyargılar çalışanların daha iyi bir iş bulduklarında işlerini bırakmaya meyilli hale getirmektedir. Bununla birlikte memurların işlerinden ayrılarak kazanılmış olan haklarını tehlikeye atmak istemedikleri saptanmıştır. Çalışmada katılımcıların devamlılık bağlılığının yüksek olduğu belirlenmiştir. Bunun nedeni ülkemizdeki yüksek işsizlik oranı ve iyi ve güvenli bir iş bulmanın zorluğu olabilir. Türkiye gibi işsizlik oranının yüksek olduğu, iş güvencesinin ve yasal hakların tam anlamıla sağlanamadığı bir ülkede işgörenlerin kaygı duymaları olağandır. Türkiye'deki istihdam koşulları, devamlılık bağlılığın da belirleyicisi olmaktadır. Tekingündüz (2012)'ün hastane personelinin örgütsel bağlılığını ölçmek amacıyla yaptığı çalışmada araştırmaya katılanların devam bağlılı̆̆ yüksek bulunmuştur.

Cevaplayıcıların tutumsal bağlılığa ilişkin katılım düzeyleri incelendiğinde; katılımcıların çalıştıkları kurumların karşılaştı̆̆ı zorluklarda, kendilerinden beklenenden daha fazlasını yapmaya istekli oldukları ve işlerinden doyum elde ettikleri sürece işlerinde kalmayı arzuladıkları saptanmıştır. Tutumsal bağlılık boyutundaki bu sonuçlar, işgörenlerin çalışmakta oldukları Kuruma yönelik bir tür vefa duygusu ve bağl1lığı içerisinde olduklarını göstermektedir.

Memurların duygusal bağlılığına ilişkin sonuçlar, katılımcıların yaptıkları işin kurumlarına olan katkısının farkında oldukları, sadece kendi amaçları için değil kurumun amaçlarını gerçekleştirmek için de çalıştıkları, katılımcıların çalıştıkları kurumu benimsedikleri ve kendileriyle özdeşleştirdikleri, sonuçta da işgörenlerin bulundukları kurumla ortak bir amaç ve kaygı paydasında buluştukları şeklinde yorumlanabilir.

Çalışmada; duygusal, devamlılık ve tutumsal bağlılık boyutları ile demografik değişkenler ve kurumun nitelikleri açısından farklılaşma olup olmadığı belirlenmeye çalışılmış ve örgütsel bağlılığın alt boyutlarının cinsiyet, yaş ve eğitim değişkenlerine göre farklılık göstermediği sonucuna ulaşılmıştır. Ancak Ertan (2008), çalışmasında; 
tüm bağlılık boyutlarında yaşa göre farklılaşma olduğu sonucuna ulaşmış ve yaş ile bağlılık arasında doğru orantılı bir ilişki olduğu tespit edilmiştir. Ayrıca örgütsel bağlılığın cinsiyet faktörüne göre farklılık gösterdiği ve erkeklerin daha yüksek düzeyde bağlılıklarının olduğu tespit edilmiştir. Yine Karcıoğlu ve Türker (2010: 121)'in Erzurum'da faaliyet gösteren hastanede çalışanları üzerinde yaptıkları araştırmada, erkek sağlık çalışanlarının kadın çalışanlara göre örgütsel bağlılık ve psikolojik sözleşmeye uyum alg1 düzeylerinin daha yüksek olduğu sonucuna ulaşılmıştır. Bu sonuçlar ışığında; erkeklerin kadınlara göre ekonomik anlamda sorumluluklarının fazla olması, evi geçindirme işini üstlenmeleri ve bunu en iyi şekilde yerine getirme arzusunda olmaları gibi sebeplerle çalıştıkları işletmelere karşı bağlllıklarının yüksek olduğu söylenebilir.

Medeni durum değişkenine göre duygusal bağlılık boyutunda farklılık olduğu bulunmuştur. Bu duruma göre evli işgörenlerin örgütsel bağlllık düzeyleri daha yüksektir. Bunun en önemli nedeni, geleneksel Türk aile yapısına göre aile reisi olan erkeğin ailesinin geçimini sağlamakla yükümlü olması dolayısıyla da kamu sektöründe iş güvenliğinin daha yüksek olması nedeniyle işe bağlılığının da yüksek olmasıdır. Bekâr işgörenlerin sorumluluklarının evli işgörenlere göre daha az olması ve bireysel bir hayat sürmeleri örgütsel bağl1lı̆̆ın düşük olmasındaki nedenlerden biri olabilir. Boşanmış işgörenlerin duygusal bağlılık boyutunun düşük olması ise; boşanmanın getirdiği sosyolojik ve psikolojik olumsuzluk kaynaklı olabilir.

Katılımcıların kurumdaki çalışma süreleri ile duygusal bağlılık boyutu arasında farklılık olduğu saptanmıştır. Çalışma süresi 1-5 ve 6-10 yıl olanların, 1 yıldan daha az süredir kurumda çalışanlara göre duygusal bağlllık düzeyleri daha düşüktür. Bunun en önemli nedeni cezaevi gibi suçla karışmış, problemli, toplum tarafından ötelenen insanların bulunduğu bir kurumda çalışma süresi arttıkça çalışanların çalışma koşullarından olumsuz etkilenmesidir.

Çalışmada, örgüsel bağlılığın kurumun bulunduğu yere göre farklılık gösterdiği tespit edilmiştir. Karabük, Bartın, Kastamonu, Bolu ve Eskipazar'daki ceza infaz kurumlarında çalışanların devam bağlılı̆̆ının Zonguldak'taki ceza infaz kurumunda çalışanlardan daha yüksek olduğu görülmektedir. Bunun yanı sıra duygusal bağlılık ile ilgili veriler incelendiğinde; Kastamonu ve Bolu'daki kurumlarda çalışanların Karabük ilindeki çalışanlara göre, ayrıca Bolu'daki kurumda çalışanların Bartın ilindeki çalışan infaz koruma memurlarına göre işlerine olan duygusal bağlılıklarının daha yüksek olduğu tespit edilmiştir.

Bu çalışmada, iş doyumu ile örgütsel bağlılık arasında pozitif yönlü bir ilişki olduğu belirlenmiştir. İşgörenlerin işlerinden doyum elde etmelerini sağlayan bir sisteme sahip kurumların, memurlarda daha fazla örgütsel bağlılık yaratığı görülmektedir. Bu nedenle yöneticiler örgütlerinde, örgütsel bağlılığ 1 artıracak etkin bir yapı kurmalıdırlar.

$\mathrm{Bu}$ çalışma iş doyumu ve örgütsel bağlılık üzerine ceza infaz kurumlarında yapılan ilk çalışma olması sebebiyle önem taşımaktadır. Bu konudaki çalışmaların artması, ceza infaz kurumlarında çalışanların sorunlarına dikkat çekilmesi, işgörenlerin 
iş koşullarının yeniden düzenlenmesi ve çeşitli araçlarla işe olan bağlılıklarının arttırılması açısından önem arz etmektedir.

\section{KAYNAKÇA}

Albayrak, E. G. (2007). Kariyer Yönetimi ve Örgütsel Bağlllık Üzerine Etkisi. Yayınlanmamış Yüksek Lisans Tezi, Maltepe Üniversitesi Sosyal Bilimler Enstitüsü, İşletme Anabilim Dalı, İstanbul.

Aşan, Ö. ve Erenler, E. (2008). İş Tatmini ve Yaşam Tatmini İlişkisi. Süleyman Demirel Üniversitesi İktisadi ve İdari Bilimler Fakültesi Dergisi, 13(2), 203-216.

Atmojo, M. (2012). The Influence of Transformational Leadership on Job Satisfaction, Organizational Commitment, and Employee Performance. International Research Journal of Business Studies, 5(2), 113-128.

Balay, R. (2000). Yönetici ve Öğretmenlerde Örgütsel Bağlılık. Ankara: Nobel Yayınları.

Bozkurt, Ö ve Bozkurt, İ. (2008). İş Tatminini Etkileyen İşletme İçi Faktörlerin Eğitim Sektörü Açısından Değerlendirilmesine Yönelik Bir Alan Araştırması. Doğuş Üniversitesi Dergisi, $9(1), 1-18$.

Ceylan, A. ve Ulutürk, Y. H. (2006). Rol Belirsizliği, Rol Çatışması, İş Tatmini ve Performans Arasındaki İlişkiler. Doğuş Üniversitesi Dergisi, 7(1), 48-58.

Chan, S. H. (2006). Organizational Identification and Commitment of Members of a Human Development Organization. Journal of Management Development, 25(3), 249-268.

Cook, J. ve Wall, T. (1980). New York Attitude Measures of Trust, Organizational Commitment and Personal Need Non - Fulfilment. Journal of Occupational Pyhschology, (53), 39-52

Çavuş, Ş. ve Gürdoğan, A. (2008). Örgüt Kültürü ve Örgütsel Bağlılık İlişkisi: Beş Yıldızlı Bir Otel İşletmesinde Araştırma. Ticaret ve Turizm Eğitim Fakültesi Dergisi, (1), 18-34.

Çekmecelioğlu, H. (2006). İş Tatmini ve Örgütsel Bağlılık Tutumlarının İşten Ayrılma Niyeti Ve Verimlilik Üzerindeki Etkilerinin Değerlendirilmesi: Bir Araştırma. "Işs, Güç" Endüstri İlişkileri ve İnsan Kaynakları Dergisi, 8(2), 153-168.

Demirel, Y. ve Özçınar, M. F. (2009). Örgütsel Vatandaşlık Davranışının İş Tatmini Üzerine Etkisi: Farklı Sektörlere Yönelik Bir Araştırma. İktisadi ve İdari Bilimler Dergisi, 23(1), 129145.

Dick, G. ve Metcalfe, B. (2001). Manegerial Factors and Organizational Commitment. The International Journal of Public Sector Management, 14, 111-128.

Ertan, H. (2008). Örgütsel Bă̆lılık, İş Motivasyonu ve İş Performansı Arasındaki İlişki: Antalya'da Beş Yıldızl Otel İşletmelerinde Bir İnceleme. Yayımlanmamış Doktora Tezi, Kocatepe Üniversitesi Sosyal Bilimler Enstitüsü, Afyonkarahisar.

Gül, H., Oktay, E., ve Gökçe, H. (2008). İş Tatmini, Stres, Örgütsel Bağl1lık, İşten Ayrılma Niyeti ve Performans Arasındaki İlişkiler: Sağlık Sektöründe Bir Uygulama. Akademik Bakış Dergisi, (15), 1-11.

Güner, A. R. (2007). Sağglık Hizmetlerinde Örgütsel Bağlllık, İşe Bağlllık ve İş Tatmini Ararsindaki İlişkilerin Modellenmesi, Yayınlanmamış Yüksek Lisans Tezi, Akdeniz Üniversitesi Sosyal Bilimler Enstitüsü, Antalya. 
Günlük, M. (2010). Muhasebecilerin Meslek ve Örgütsel bağlllık, İş Memnuniyeti ve İşten Ayrılma Eğilimleri Üzerine Bir Araştırma. Yayınlanmamış Doktora Tezi, Gebze Yüksek Teknoloji Üniversitesi Sosyal Bilimler Enstitüsü, Gebze.

Izgar, H. (2008). Okul Yöneticilerinde İş Doyumu ve Örgütsel Bağlllık. Selçuk Üniversitesi Ahmet Keleşŏ̆lu Eğitim Fakültesi Dergisi, (25), 317-334.

İlgün, E. (2010).İnfaz Koruma Memurlarının İş Doyumu ve Tükenmişlik Düzeylerinin Bazı Değişkenlere Göre İncelenmesi. Yayınlanmamış Yüksek Lisans Tezi, Selçuk Üniversitesi Sosyal Bilimler Enstitüsü Rehberlik ve Psikolojik Danışmanlık Ana Bilim Dalı, Konya.

Karcıoğlu, F. ve Türker, E. (2010). Psikolojik Sözleşme İle Örgütsel Bağlllık İlişkisi: Sağlık Çalışanları Üzerine Bir Uygulama. Atatürk Üniversitesi İktisadi ve İdari Bilimler Dergisi, 24(2), 121-140.

Kartal, R. C. (2012). Özel Güvenlik Görevlilerindeki İş Doyum Düzeyinin Bireysel Demografik Değişkenler Açısından İncelenmesi. Akademik Bakış Dergisi, (30), 1-18.

Kitapçı, H. ve Sezen, B. (2002). Çalısanların İş Tatminini Belirleyici Unsurlar Üzerine Bir Arastırma: Kariyer Süreci Örnegi. Firat Üniversitesi Sosyal Bilimler Dergisi, 12 (1), 219230.

Meyer, J. P. ve Herscovitch, L. (2001). Commitment in the Workplace: Toward a General Model. Human Resource Management Review, (11), 299-326.

Mohamed, M. S., Abdulkader, M. M. ve Anisa, H. (2012). Relationship Among Organizational Commitment, Trust and Job Satisfaction: An Empirical Study in Banking Industry. Research Journal of Management Sciences, 1(2), 1-7.

Omidifar, R. (2013). Leadership Style, Organizational Commitment and Job Satisfaction: A Case Study on High School Principals in Tehran, Iran. American Journal of Humanities and Social Sciences, 1(4), 263-267.

Özdevecioğlu, M. (2003). Algılanan Örgütsel Destek İle Örgütsel Bağlılık Arasındaki İlişkilerin Belirlenmesine Yönelik Bir Araştırma. D.E.Ü. İ.I.B.F. Dergisi, 18(2), 113-130.

Öztürk, A. ve Güzelsoydan, Y. S. (2001). Büyük Mağazalarda Çalışan Personelin İş Doyumu Üzerine Çukurova Bölgesinde Bir Araştırma. İktisadi ve İdari Bilimler Dergisi, 15(1-2), 333-345.

Pandey, C. ve Khare, R. (2012). Impact of Job Satisfaction and Organizational Commitment on Employee Loyalty. International Journal of Social Science \& Interdisciplinary Research, 1(8), 26-41.

Saldamlı, A. (2008). Otel İşletmelerinde Bölüm Yöneticilerinin İş ve Yaşam Tatminini Belirlemeye Yönelik Bir Alan Araştırması. Marmara Üniversitesi İ.I.B.F. Dergisi, 25(2), 694-719.

Sönmezer, M. G. ve Eryaman, M. Y. (2008) Kamu ve Özel Eğitim Kurumlarında Çalışan Öğretmenlerin İş Tatmin Düzeylerinin Karşılaştırılması, Eğitimde Kuram ve Uygulama, 4 (2), 189-212

Taşdan, M. ve Tiryaki, E. (2008). Özel ve Devlet İlköğretim Okulu Öğretmenlerinin İş Doyumu Düzeylerinin Karşılaştırılması. Eğitim ve Bilim, 33(147), 54-70. 
Tekingündüz, S. (2012). Örgütsel Bağllllk Üzerinde Örgütsel Güven ve İş Tatmininin Etkisinin Belirlenmesine Yönelik Bir Alan Çalışması. Yayınlanmamış Doktora Tezi, Gazi Üniversitesi Sosyal Bilimler Enstitüsü, Ankara.

Toker, B. (2007). Demografik Değişkenlerin İş Tatminine Etkileri: İzmir'deki Beş ve Dört Yıldızlı Otellere Yönelik Bir Uygulama. Doğuş Üniversitesi Dergisi, 8(1), 92-107.

Tolay, E. (2003). Eğitimin Örgütsel Bă̆hllı̆̆a Etkisi. Yayınlanmamış Yüksek Lisans Tezi, Dokuz Eylül Üniversitesi Sosyal Bilimler Enstitüsü, İzmir.

Tor, S. (2011). Örgütlerde İş Tatminini Etkileyen Demografik Faktörler ve Verimlilik:Karaman Gıda Sektöründe Bir Uygulama. Yayınlanmamış Yüksek Lisans Tezi, Karamanoğlu Mehmetbey Üniversitesi Sosyal Bilimler Enstitüsü İşletme Anabilim Dalı,Karaman.

Yapraklı, Ş. ve Yılmaz, M. K. (2007). Satış Gücü Motivasyonu - İş Tatmini Ölçeklerinin Test Edilmesi ve Motivasyonun İş Tatmini Üzerindeki Etkisinin Belirlenmesi: İlaç Sektöründe Bir Uygulama. "İş, Güç” Endüstri İlişkileri ve İnsan Kaynakları Dergisi, 9(3), 6298.

Yavuz, E. ve Tokmak, C. (2009). Işgörenlerin Etkileşimci Liderlik ve Örgütsel Bağlllık ile İlgili Tutumlarına Yönelik Bir Araştırma, International Journal of Economic and Administrative Studies, 1 (2), 17-35

Yazıcıoğlu, İ. ve Sökmen, A. (2007). Otel İşletmelerinin Yiyecek-İçecek Departmanlarında Görev Yapan İşgörenlerin İş Tatmin Düzeylerinin Değerlendirilmesi: Adana'da Bir Uygulama", Muğla Üniversitesi SBE Dergisi, Sayı:18, www.mu.edu.tr/sbe/sbedergi/dosya/i-yazicioglu.Pdf, Erişim Tarihi: 21.05.2014.

Yıldız, G., Akabolat, M. ve Işık, O. (2013). Psikolojik Taciz Ve Örgütsel Bağlılık: Sağlık Çalışanları Üzerine Bir Araştırma. Manas Sosyal Araştırmalar Dergisi, 2(6), 85-117.

Yiğit, R., Dilmaç, B. ve Deniz, M. E. (2011). İş ve Yaşam Doyumu: Konya Emniyet Müdürlüğü Alan Araştırması. Polis Bilimleri Dergisi, 13(3), 1-18.

Yüceler, A. (2009). Örgütsel Bağlllık ve Örgüt İklimi İlişkisi: Teorik ve Uygulamalı Bir Çalışma, Selçuk Üniversitesi Sosyal Bilimler Enstitüsü Dergisi, (22), s.455-458.

Yüksel, İ. (2005). İletişimin İş Tatmini Üzerindeki Etkileri: Bir İşletmede Yapılan Görgül Çalışma. Doğuş Üniversitesi Dergisi, 6(2), 291-306. 